\title{
Comparative Study on Quantitative and Qualitative Characters of Different Oat (Avena sativa L.) Genotypes under Agro-Climatic Conditions of Sargodha, Pakistan
}

\author{
Adeel Khan1*, Maqbool Hussain Anjum², Muhammad Khashi U. Rehman, \\ Qamar uz Zaman', Raza Ullah ${ }^{4}$ \\ ${ }^{1}$ Department of Plant Breeding and Genetics, University of Agriculture, Faisalabad, Pakistan \\ ${ }^{2}$ Fodder Research Institute, Sargodha, Pakistan \\ ${ }^{3}$ Department of Horticulture, PMAS-Arid Agriculture University, Rawalpindi, Pakistan \\ ${ }^{4}$ Department of Agronomy, University of Agriculture, Faisalabad, Pakistan \\ Email: adeel.tiger3@gmail.com
}

Received 11 July 2014; revised 24 August 2014; accepted 24 September 2014

Copyright (C) 2014 by authors and Scientific Research Publishing Inc.

This work is licensed under the Creative Commons Attribution International License (CC BY). http://creativecommons.org/licenses/by/4.0/

c) (i) Open Access

\begin{abstract}
An experiment was conducted to compare the forage yield and qualify of oat (Avena sativa L.) genotypes (F-413, SGD-46, F-408, F-301, SGD-2011, SGD-3, SGD-37, SGD-40, SGD-5 and S-2000) at Fodder Research Institute, Sargodha, Pakistan during the year 2011 to 2012 . Experiment was laid out in randomized complete block design (RCBD) having three replications and a net plot of size $1.6 \times 5 \mathrm{~m}$. The varieties were differed significantly $(P \leq 0.05)$ in yield, growth and quality parameters. The variety SGD-40 produced significantly higher green forage yield $\left(80.00 \mathrm{t}^{-h^{-1}}\right)$ and dry matter yield (10.95 th.ha-1) than other varieties due to taller plants $(145.73 \mathrm{~cm})$, more number of tillers $\left(7.78 \mathrm{~m}^{-2}\right)$ and leaf area per plant $\left(95.08 \mathrm{~cm}^{2}\right)$. It also had the highest crude protein percentage $(13.84 \%)$. Correlation analysis of quantitative and qualitative characters indicated the strongly positive association of green forage yield with dry matter, crude protein and ash content. While green forage yield was negatively correlated with the number of tillers per plant, keeping in view both forage yield and crude protein contents the genotype SGD-40 grown under the condition of Sargodha (Pakistan).
\end{abstract}

\footnotetext{
*Corresponding author.
}

How to cite this paper: Khan, A., Anjum, M.H., Rehman, M.K.U., Zaman, Q. and Ullah, R. (2014) Comparative Study on Quantitative and Qualitative Characters of Different Oat (Avena sativa L.) Genotypes under Agro-Climatic Conditions of Sargodha, Pakistan. American Journal of Plant Sciences, 5, 3097-3103. http://dx.doi.org/10.4236/ajps.2014.520326 


\section{Keywords}

\section{Crude Protein, Crude Fiber, Forage Yield, Genotypes}

\section{Introduction}

In agriculture sector livestock is a vital component because 30\% - 35\% rural population of Pakistan is involved in livestock rearing. The demand of milk, butter, meat, beef, and their byproducts is escalating due to rapidly growing population in Pakistan. In Pakistan animals are mainly deficient both in protein and energy by $60 \%$ and $40 \%$, respectively [1]. For a more efficient and productive industry of livestock production of superior quality forage in huge quantity is the essential requirement. To run an efficient livestock industry high yielding and nutritious fodder cultivars are needed. The present fodder supply is $1 / 3$ less than the actual needs of animals [2].

Fodder production and fodder species mainly depend on the climatic factors like (frost, temperature, availability of water, duration of winter, growth period length, distribution of rainfall) and the soils factors like (texture, structure) [3]. Oat is the main winter fodder which grows best at temperature of $16^{\circ} \mathrm{C}-32^{\circ} \mathrm{C}$ and $400 \mathrm{~mm}$ healthy distributed rainfall [4]. Oat has the advantage of being winter hardy and serves as catch crop [5]. It prefers feed of all animals and its straw is soft and grain is also valuable feed for dairy cows, horses, young breeding animals and poultry.

The farmers face fodder shortage in winter when they have only dry stalks of summer cereal fodders or dry summer grasses. The improved varieties of oat can produce three-fold green fodder, that is, 60 to 80 tones/ha and can feed double number of animals per unit area as against the traditional fodder crops [6]. With the introduction of new high-yielding oat varieties, the farmers in KPK have recognized oat as important winter fodder for filling the fodder gap [7]. Many cultivars of oat have high feed value if cut at flowering stage or soon after it and it can meet the demand of rapidly growing livestock industry of Pakistan. Ideal variety is always one, which possesses general adaptation with higher yield potential [8]. Therefore, a field experiment with seven oat varieties was under taken to evaluate and identify suitable variety for Sargodha area.

\section{Materials and Methods}

The study was carried out using a randomized complete block design (RCBD) with three replications at Fodder Research Institute, Sargodha, Pakistan during the year 2011 to 2012. The net plot size was $1.6 \mathrm{~m} \times 5 \mathrm{~m}$. The experiment comprised 10 oat genotypes (F-413, SGD-46, F-408, F-301, SGD-2011, SGD-3, SGD-37, SGD-40, SGD-5 and S-2000) for their green forage yield. The fertilizer was applied @ 80: 60: $00 \mathrm{~kg} \cdot \mathrm{ha}^{-1} \mathrm{NPK}$, respectively. All of phosphorous, and half of the nitrogen were applied at the time of sowing in the form of DAP (Diammonium Phosphate) and Urea. Remaining nitrogen was applied with first irrigation. All the other practices maintained normal and uniform.

The soil of the experimental site was subjected to physio-chemical analysis and its textural class was found to be clay-loam with slightly alkaline reaction ( $\mathrm{pH} 8.3$ ) and organic matter percentage of $0.74 \%$. Total nitrogen, available phosphorus and potassium contents were $0.025 \%, 3.33 \mathrm{ppm}$ and $380 \mathrm{ppm}$, respectively. Data collected on all parameters was analyzed statistically by using fisher's analysis of variance technique and least significant (LSD) test at 5\% probability level was applied to compare the treatment means [9].

\subsection{Yield Parameters}

Fresh fodder yield $\left(\mathbf{t} \cdot \mathbf{h a}^{-\mathbf{1}}\right)$ : At $50 \%$ flowering stage, all treatments were harvested and weighed to get fresh fodder yield (FFY). The yields obtained were converted into $t \cdot \mathrm{ha}^{-1}$.

Dry matter (\%): For dry matter determination, firstly aluminum containers were oven dried and weighed by electric balance. $10 \mathrm{~g}$ of plant sample was weighed in each container and placed in an oven at $105^{\circ} \mathrm{C}$ till constant weight was attained. Dry matter percentage was calculated by the given formula.

Dry Matter $(\%)=($ Wt. of oven dry sample/Wt. of sample before drying $) \times 100$

Dry matter yield $\left(\mathbf{t} \cdot \mathbf{h a}^{-1}\right)$ : Dry fodder yield (DMY) was calculated by applying this formula. 
$\operatorname{DMY}\left(\mathrm{t} \cdot \mathrm{ha}^{-1}\right)=\mathrm{FFY} \times \mathrm{DM}(\%) / 100$

\subsection{Quality Parameters}

Quality parameters like crude protein, crude fibre, ash and ether extractable fat were determined by following methods.

Crude protein (\%): To $1.0 \mathrm{~g}$ of an oven dried plant material, $25 \mathrm{ml}$ of commercial $\mathrm{H}_{2} \mathrm{SO}_{4}$ and $5 \mathrm{~g}$ of digestion mixture $\left(\mathrm{K}_{2} \mathrm{SO}_{4}: \mathrm{FeSO}_{4}: \mathrm{CuSO}_{4}=85: 5: 10\right)$ was added and then digested the plant material in the digestion chamber unless transparent and colorless contents appeared, cooled and made the volume up to $250 \mathrm{ml}$ and then $10 \mathrm{ml}$ was taken from this for distillation. Nitrogen evolved as ammonia was collected in receiving flask containing boric acid solution (4\%) and mixed indicator (methyl red) till the end point that was appearance of golden colour. The boric acid solution titrated against $\mathrm{N} / 10 \mathrm{H}_{2} \mathrm{SO}_{4}$ till pink colour appears. The volume of acid used was recorded and $\mathrm{N} \%$ was calculated by the formula given below.

$$
\mathrm{N} \%=\frac{\text { Vol. of } \mathrm{N} / 10 \mathrm{H}_{2} \mathrm{SO}_{4} \times \text { Vol. of sample sol. } \times 0.0014}{\text { Wt. of sample } \times \text { Vol. of sample sol. Used }(10 \mathrm{ml})} \times 100
$$

Crude protein percentage was obtained by multiplying nitrogen percentage with factor 6.25 .

Crude fiber (\%): One gram of oven dried material was taken in $250 \mathrm{ml}$ beaker and then added $200 \mathrm{ml}$ of $1.25 \% \mathrm{H}_{2} \mathrm{SO}_{4}$. It was placed on flame for 30 minutes at simmering temperature and filtered the contents through thick linen cloth and washed the residue three times with distilled water. The residue was transferred in another beaker containing $1.25 \% \mathrm{NaOH}$ solution $(200 \mathrm{ml})$, heated it again for 30 minutes at simmering temperature, filtered and washed. The sample was placed in pre-weighed crucible $\left(\mathrm{W}_{1}\right)$ and placed the crucible on flame and ignited. When smoke disappeared, placed it in a muffle furnace 27 and heated up to $600^{\circ} \mathrm{C}-650^{\circ} \mathrm{C}$ for 3 - 4 hours. Then cooled it in the desiccators and reweighed $\left(\mathrm{W}_{2}\right)$. The crude fiber percentage was calculated by using following formula.

$$
\text { Crude fiber }(\%)=\left(\mathrm{W}_{1}-\mathrm{W}_{2} / \text { Sample Weight }\right) \times 100
$$

Total ash (\%): An empty dried crucible was taken and weighed. Then a sample of $2.0 \mathrm{~g}\left(\mathrm{~W}_{1}\right)$ of dried plant material was taken in it. It was burn on the flame then was placed in a Muffle furnace at $600^{\circ} \mathrm{C}-650^{\circ} \mathrm{C}$ until white and grey ash was obtained. After this, the crucible was placed in desiccators for cooling and recoded the weight $\left(\mathrm{W}_{2}\right)$. Total ash percentage was calculated as under.

$$
\operatorname{Ash}(\%)=\left(\mathrm{W}_{1}-\mathrm{W}_{2} / \text { Sample Weight }\right) \times 100
$$

Analysis procedures described by [10] were followed for the determination of crude protein, crude fiber and total ash.

\section{Results and Discussion}

\subsection{Quantitative Traits in (Avena sativa $\mathrm{L}$. )}

\subsubsection{Plant Height}

Plant height is a major factor contributing towards forage yield of different crops. The data presented in table 1 shows that different genotypes significantly affected the plant height of oat genotypes. The genotypes SGD-37 produced the maximum plant height $(145.67 \mathrm{~cm})$ but it did not statistically different with SGD-40, showed plant height $(144.73 \mathrm{~cm})$ while the minimum plant height $(119.17 \mathrm{~cm})$ indicated by genotype SGD-46. High yielding varieties of oat tend toward more plant height these were also reported by [11] [12] and [13]. The main cause of those differences in plant height is due to differences in genetic makeup of genotypes. Significant differences among the varieties regarding plant height have also been reported by [14] and [15].

\subsubsection{Leaf Area}

In the production of final biomass of the crop and fodder quality leaf area plays an important role. The data given in Table 1 shows that different genotypes significantly differ from one another regarding to leaf area. The results showed that maximum leaf area of $\left(95.08 \mathrm{~cm}^{2}\right)$ of genotype SGD-40 it is also statically at par with SGD-2011 compared to all other genotypes while minimum leaf area $\left(80.09 \mathrm{~cm}^{2}\right)$ was recorded in genotype 
Table 1. Mean values of some yield traits of oat as affected by different cultivars.

\begin{tabular}{|c|c|c|c|c|c|c|}
\hline Genotypes & $\begin{array}{c}\text { Plant Height } \\
\text { (cm) }\end{array}$ & $\begin{array}{c}\text { Leaf Area } \\
\left(\mathrm{cm}^{2}\right)\end{array}$ & $\begin{array}{c}\text { Number of } \\
\text { Leaves Plant }^{-1}\end{array}$ & $\begin{array}{c}\text { Number of } \\
\text { Tillers per Plant }\end{array}$ & $\begin{array}{l}\text { Green Forage } \\
\text { Yield (ton/ha) }\end{array}$ & $\begin{array}{l}\text { Dry Matter } \\
\text { Yield (ton/ha) }\end{array}$ \\
\hline F-413 & $134.00 \mathrm{c}$ & $87.43 \mathrm{~d}$ & $5.93 d$ & 7.67a & 70.76de & 8.25 cde \\
\hline S-2000 & $127.50 \mathrm{e}$ & $84.94 \mathrm{e}$ & $5.87 d$ & 7.00ab & $68.87 e$ & $7.40 \mathrm{e}$ \\
\hline SGD-46 & $119.17 \mathrm{f}$ & $84.95 \mathrm{e}$ & $6.61 b c$ & 7.07ab & $76.59 \mathrm{bc}$ & 8.76cde \\
\hline F-408 & $138.74 \mathrm{~b}$ & $85.67 e$ & $6.20 \mathrm{~cd}$ & 7.00ab & $74.77 \mathrm{c}$ & 7.92de \\
\hline F-301 & $133.97 \mathrm{c}$ & $92.1 \mathrm{~b}$ & $6.67 \mathrm{bc}$ & 7.03ab & $76.63 \mathrm{bc}$ & 8.67cde \\
\hline SGD-2011 & 131.37d & $93.83 a$ & 7.13ab & $6.33 \mathrm{~b}$ & $77.52 b$ & 10.58ab \\
\hline SGD-3 & $140.77 b$ & $90.07 \mathrm{c}$ & $6.68 \mathrm{bc}$ & $6.67 \mathrm{~b}$ & $78.02 b$ & 9.73abc \\
\hline SGD-37 & $144.67 \mathrm{a}$ & $80.09 \mathrm{f}$ & 6.99ab & $7.67 a$ & 78.09ab & $10.61 a$ \\
\hline SGD-40 & 145.73a & $95.08 \mathrm{a}$ & 7.50a & 7.78a & $80.00 \mathrm{a}$ & $10.95 a$ \\
\hline SGD-50 & $139.57 b$ & $84.48 \mathrm{e}$ & $6.32 \mathrm{bc}$ & $6.33 b$ & $71.89 \mathrm{~d}$ & 9.01bcd \\
\hline LSD value & 2.56 & 1.26 & 0.64 & 0.95 & 1.96 & 1.57 \\
\hline
\end{tabular}

Means not sharing same letter differ significantly using LSD at 5\% probability level.

SGD-37. The genetic makeup of the genotypes might have been the cause of these differences among the leaf area. Significant differences among the genotypes for leaf area per plant were reported by [16]. Higher leaf area, which is responsible for higher activities of photosynthesis and higher will be, assimilates of photosynthetic products [17]. These similar findings were also reported by [13] [18] [19].

\subsubsection{Number of Tillers}

The data presented in the Table 1 regarding the number of tillers per plant of oat cultivars as affected by different genotypes revealed that number of tillers per plant were significantly affected by different genotypes. SGD-40 showed maximum number of tillers (7.78) that was statistically at par with rest of the genotypes. All other treatments showing non-significant results but they are also promising line for this trait ranging from 6.33 to 7.07 numbers of tillers per plant. Significant variation among the oat varieties for number of tillers have been reported by [11] and [20].

\subsubsection{No. of Leaves Plant ${ }^{-1}$}

The number of leaves play vital role in growth and development of plant. The increase or decrease in number of leaves per tiller has a direct effect on the yield of forage crops. The data regarding number of leaves per plant is shown in Table 1. The effect of different genotypes on number of leaves per plant was significant and number of leaves per plant varied from 7.50 to 5.93 (Table 1). The genotype SGD-40 produced the maximum number of leaves per plant (7.50) and it did not differ significantly from SGD-2011 which produced (7.13) and SGD-37 which produced (6.99) number of leaves per plant. The lowest numbers of leaves per plant (5.93) were produced by F-413. The results obtained are in line with those of [21].

\subsubsection{Green Fodder Yield}

Data on green fodder yield $\left(\mathrm{t} \cdot \mathrm{ha}^{-1}\right)$ showed that green fodder yield varied significantly among the varieties (Table 1). Green fodder yield maximum (16.16\% over S-2000) increase in green fodder yield was observed when SGD-40 is used. It is followed by SGD-37, SGD-3, SGD-2011, F-301 and SGD-46, that were increase in green fodder yield ranging from (11.20\% to $13.38 \%)$ as compared to respective S-2000 but all these treatments were statistically at par with SGD-40. While F-408 was also improved the green fodder yield up-to 8\% but statistically significant in comparison with S-2000. The variety SGD-40 produced higher yield due to more plant height, number of leaves, leaf area per plant and number of tillers $\mathrm{m}^{-2}$. [22] also reported significant differences among the oat cultivars regarding green forage yield. [17] stated that higher yields of fodder in oat cultivars can be possibly attributed to their greater leaf area, responsible for more photosynthetic activities, having high capacity to store assimilative products of photosynthesis. These results are inconformity with [13] [15] [18] [19]. 


\subsubsection{Dry Matter}

Statistical analysis of dry matter yield revealed that SGD-40 showed significant results by giving the maximum dry matter yield $\left(10.95 \mathrm{t} \cdot \mathrm{ha}^{-1}\right)$ that was statistically at par with SGD-37 which gave (10.61 t $\left.\mathrm{ha}^{-1}\right)$, SGD-2011 which gave $\left(10.58 \mathrm{t} \cdot \mathrm{ha}^{-1}\right)$ and SGD-3 which gave $\left(9.73 \mathrm{t} \cdot \mathrm{ha}^{-1}\right)$ and of dry matter yield. While genotype S-2000

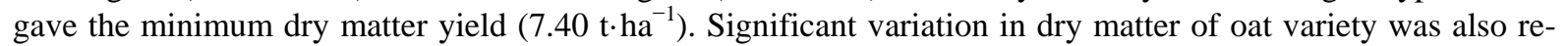
ported by [7] and [17].

\subsection{Qualitative Traits in (Avena sativa L.)}

\subsubsection{Crude Protein}

Crude protein is the important factor which affects the quality of forage. Crude protein contents varied significantly among the oat varieties (Table 2). The genotype SGD-40 had significantly higher crude protein contents (13.84\%) and it was statistically at par SGD-50 which gave (12.76\%) and SGD-2011which gave (12.66\%). The genotype F-301 produced lowest crude protein contents (9.72\%), however, it did not differ significantly from cultivars F-408 and F-413. These results confirmed the findings of [23] and [24]. However, these results are contradictory to those of [7] who reported that crude protein contents did not differ significantly among the varieties. These contradictory results can be attributed to variation in soil fertility status and climatic conditions [7].

\subsubsection{Crude Fiber}

Fiber contents greatly increased with delay in harvesting and ultimately reduced its digestibility. The data regarding the crude fiber percentage presented in Table 2 clearly showed that crude fiber percentage varied significantly among the varieties. The genotype F-408 gave the maximum crude protein (36.95\%) that was statistically at par with F-413 and SGD-46. The minimum (27.46\%) crude fiber contents were noted in genotype SGD-37. These significant differences may be due to variation in plant growth stage at harvest. These results are in agreement with those of [15] and [25].

\subsubsection{Ash Content}

Statistically analysis showed significant differences among genotypes for ash content percentage. The data regarding ash contents in Table 2 which showed maximum ash content (14.78\%) for genotype SGD-40 followed by SGD-37 which gave ash content (13.52\%) and F-408 which gave ash content (13.33\%). The genotype F-413 showed minimum ash content (10.47\%). It can be concluded from these results that varieties varied in efficiency to absorb nutrients, which may be due to variable rooting depth and rooting pattern.

\section{Correlation Analysis}

Correlation analysis was used to determine the characters which are associated with green forage yield. Plant height $(\mathrm{PH})$ was significantly associated with dry matter yield and ash content percentage (AC) but significant as shown in (Table 3). There was negatively association with crude fiber (CF). Non-significant association was

Table 2. Mean values of some quality traits of oat as affected by different cultivars.

\begin{tabular}{|c|c|c|c|}
\hline Genotypes & Crude Protein (\%) & Crude Fiber (\%) & Ash Content (\%) \\
\hline F-413 & 10.56de & 35.71ab & $10.47 d$ \\
\hline S-2000 & $11.84 \mathrm{bcd}$ & $31.65 \mathrm{~d}$ & $11.72 \mathrm{c}$ \\
\hline SGD-46 & $11.78 \mathrm{bcd}$ & 34.59abc & 11.60cd \\
\hline F-408 & 10.86cde & $36.45 a$ & $13.33 b$ \\
\hline F-301 & $9.72 \mathrm{e}$ & $32.43 d$ & $12.41 \mathrm{bc}$ \\
\hline SGD-2011 & 12.66ab & $31.61 \mathrm{~d}$ & $13.57 b$ \\
\hline SGD-3 & $12.20 \mathrm{bc}$ & $24.49 \mathrm{bc}$ & $12.72 \mathrm{bc}$ \\
\hline SGD-37 & 13.36ab & $27.46 \mathrm{e}$ & $13.52 b$ \\
\hline SGD-40 & $13.84 a$ & $26.52 \mathrm{e}$ & $14.78 \mathrm{a}$ \\
\hline SGD-50 & 12.76ab & $33.27 \mathrm{~cd}$ & $10.51 d$ \\
\hline LSD value & 1.61 & 1.91 & 1.17 \\
\hline
\end{tabular}

Means not sharing same letter differ significantly using LSD at 5\% probability level. 
Table 3. Correlation coefficients of some yield and quality traits of oat as affected by different cultivars.

\begin{tabular}{|c|c|c|c|c|c|c|c|c|}
\hline Characters & $\mathrm{PH}$ & LA & NL & NT & GFY & DM & $\mathrm{CP}$ & $\mathrm{CF}$ \\
\hline LA & 0.0752 & & & & & & & \\
\hline NL & 0.3343 & $0.4309^{*}$ & & & & & & \\
\hline NT & 0.2185 & -0.0050 & 0.1607 & & & & & \\
\hline GFY & 0.3173 & 0.3223 & $0.6851^{* *}$ & 0.0303 & & & & \\
\hline $\mathrm{DM}$ & $0.4631^{* *}$ & 0.2834 & $0.6756^{* *}$ & 0.1272 & $0.7111^{* *}$ & & & \\
\hline $\mathrm{CP}$ & 0.3526 & -0.0305 & $0.5363^{* *}$ & 0.1122 & $0.3573^{*}$ & $0.7366^{* *}$ & & \\
\hline $\mathrm{CF}$ & $-0.4164^{*}$ & -0.1333 & $-0.5234^{* *}$ & -0.2842 & $-0.4162^{*}$ & $-0.5312^{* *}$ & $-0.5248^{* *}$ & \\
\hline AC & $0.4925^{* *}$ & 0.4061 & 0.6148 & 0.2442 & $0.5976^{* *}$ & $0.5812^{* *}$ & $0.3761^{*}$ & $-0.4707^{* *}$ \\
\hline
\end{tabular}

Correlation coefficient among genotypes representing significant differences at 5\%. PH: Plant Height; LA: Leaf Area; NL: Number of Leaves; NT: Number of Tillers; GFY: Green Forage Yield; DM: Dry Matter; CP: Crude Protein; CF: Crude Fiber; AC: Ash Content.

found between PH with leaf area (LA), number of leaves (NL), number of tillers per plant (NT), green forage yield (GFY) and crude protein $(\mathrm{CP})$. Leaf area showed significant $(\mathrm{P} \leq 0.05)$ and positive association with NL, GFY and DM. Positive non-significant relation was found between LA with GFY, DM and AC. While negatively non-significant $(\mathrm{P} \leq 0.05)$ correlation was present between LA with NT and CF. Number of leaves per plant showed strong positive association with DM, LA, GFY, CP and AC. While non-significantly association was showed with NT. There was negatively relation between NL and CF but significant. Neither positive nor negative association was found between NT with GFY, DM, CP and AC. There was negatively relation $(\mathrm{P} \leq$ 0.05) was present between NT with CF but insignificant. GFY was positively strongly associated with DM, CP and AC. While negatively correlated with CF but significant. DM had strongly positive association with CP and AC while negatively correlation with CF. There was positively relation between CP with AC. Fiber content percentage showed negatively association with AC and CP but significant.

\section{Conclusion}

The results showed that oat genotypes have great variations regarding yield and quality parameters. There is a need to compromise between yield and quality, however, the genotype SGD-40 performed better than other genotypes regarding yield. So for getting higher forage yield the variety SGD-40 should be sown under Sargodha conditions.

\section{References}

[1] Sial, M.A. and Aalam, M.Z. (1988) Livestock Feed Resources Scenario of Pakistan. National Seminar on Dairy Production Potential and Challenges, Faisalabad, 29-30 May 1988.

[2] Younas, M. and Yaqoob, M. (2005) Food Research Source of Livestock in the Punjab, Pakistan. Livestock Research for Rural Development, 17, 18.

[3] Bruzon, V. (2007) EC/GOP Project ALA/01/129, Strengthening of Livestock Services Project.

[4] Bhatti, M.B., Hussain, A. and Mohammad, D. (1992) Fodder Production Potential of Different Oat Cultivars under Two Cut Systems. Pakistan Journal of Agricultural Research, 13, 184-190.

[5] Morey, D.D. (1961) Forage Production of Small Grains under Maximum Favorable Condition. Agronomy Journal, 53, 57-59. http://dx.doi.org/10.2134/agronj1961.00021962005300010023x

[6] Haqqani, A.M., Ali, Z.S., Shafique, S., Zahid, S. and Bakhsh, A. (2003) Oats: A Fodder of Winter Lean Period. Agridigest, 23, 15-23.

[7] Habib, G., Ahmad, T., Saba, I. and Akhtar, N. (2003) Genotypes Variation in Yield and Nutritive Quality of Oats Fodder. Sarhad Journal of Agriculture, 19, 419-422.

[8] Finlay, K.W. and Wilkinson, G.N. (1963) The Analysis of Adaptation in a Plant-Breeding Programme. Crop and Pasture Science, 14, 742-754. http://dx.doi.org/10.1071/AR9630742

[9] Steel, R.G.D., Torrie, J.H. and Dickey, D.A. (1997) Principles and Procedures of Statistics: A Biometrical Approach. McGraw Hill Book Company, New York.

[10] AOAC (1984) Official Methods of Analysis. Association of Official Analytical Chemists. 14th Edition, AOAC, Arlington. 
[11] Naeem, M., Chohan, M.S.M., Khan, A.H. and Kainth, R.A. (2006) Green Fodder Yield Performance of Oats Varieties under Irrigated Conditions. Journal of Agriculture of Research, 44, 197-120.

[12] Zaman, Q., Hussain, M.N., Aziz, A. and Hayat, K. (2006) Performance of High Yielding Oat Varieties under AgroEcological Conditions of D. I. Khan. Journal of Agriculture Research, 44, 29-35.

[13] Ayub, M., Shehzad, M., Nadeem, M.A., Pervez, M., Naeem, M. and Sarwar, N. (2011) Comparative Study on Forage Yield and Quality of Different Oat (Avena sativa L.) Varieties under Agro-Ecological Conditions of Faisalabad, Pakistan. African Journal Agriculture Research, 6, 3388-3391.

[14] Chohan, M.S.M., Naeem, M., Khan, A.H., Kainth, R. and Sarwar, M. (2004) Forage Yield Performance of Different Varieties of Oat. International Journal of Agriculture and Biology, 6, 751-752.

[15] Hussain, A., Muhammad, D., Khan, S. and Bhatti, M.B. (1993) Forage Yield and Quality Potential of Various Cultivars of Oats (Avena sativa L.). Pakistan Journal of Scientific and Industrial Research, 36, 258-260.

[16] Zafar, N. (2009) Forage Growth, Yield and Quality Performance of Different Oat (Avena sativa L.) Cultivars under Agro-Ecological Conditions of Faisalabad. M.Sc. Thesis, Department of Agronomy, University of Agriculture, Faisalabad.

[17] Amanullah, P.S., Zada, K. and Perveen, S. (2004) Growth Characters and Productivity of Oat Varieties at Peshawar. Sarhad Journal of Agriculture, 20, 5-10.

[18] Naeem, M., Chohan, M.S.M., Khan, A.H. and Kainth, R.A. (2006) Green Fodder Yield Performance of Oats Varieties under Irrigated Conditions. Journal of Agricultural Research, 44, 197-120.

[19] Lodhi, M.Y., Marghazani, I.B., Hamayun, K. and Marri, M.J. (2009) Comparative Performance Study of Different Oat Varieties under Agro-Climatic Conditions of Sibi. Journal Animal Plant Sciences, 19, 34-36.

[20] Naeem, M., Khan, M.A., Chohan, M.S.M., Khan, A.H. and Salahuddin S. (2002) Evaluation of Different Varieties of Oat for Green Fodder Yield Potential. Asian Journal of Plant Science, 1, 640-641. http://dx.doi.org/10.3923/ajps.2002.640.641

[21] Naeem, M., Kainth, R.A., Chohan, M.S.M. and Khan, A.H. (2005) Study on Fodder Yield Potential of Different Oats Varieties under Irrigated Conditions. Pakistan Journal of Agriculture Research, 43, 27-31.

[22] Nawaz, N., Razzaq, A., Ali, Z. and Yousaf, M. (2004) Performance of Different Oat (Avena sativa L.) Varieties under the Agro-Climatic Conditions of Bahawalpur, Pakistan. International Journal of Agriculture and Biology, 6, 624-626.

[23] Chaudhry, M.H. and Mukhtar, M.A. (1985) Performance of Three New High Fodder Yielding Varieties of Oat. Pakistan Journal of Agriculture Research, 6, 218-222.

[24] Mufti, M.U., Hussain, A., Zahid, Khan, S.S. and Bahtti, M.B. (1996) Genetic Variability and Correlation Studies in Forage Oat. Journal of Agriculture Research, 34, 93-97.

[25] Rasmusson, D.C. and Steve, R.S. (1994) Forage Yield and Quality of Semi Dwarf Barley. Crop Science, 34, 16621665. http://dx.doi.org/10.2135/cropsci1994.0011183X003400060044x 
Scientific Research Publishing (SCIRP) is one of the largest Open Access journal publishers. It is currently publishing more than 200 open access, online, peer-reviewed journals covering a wide range of academic disciplines. SCIRP serves the worldwide academic communities and contributes to the progress and application of science with its publication.

Other selected journals from SCIRP are listed as below. Submit your manuscript to us via either submit@scirp.org or Online Submission Portal.
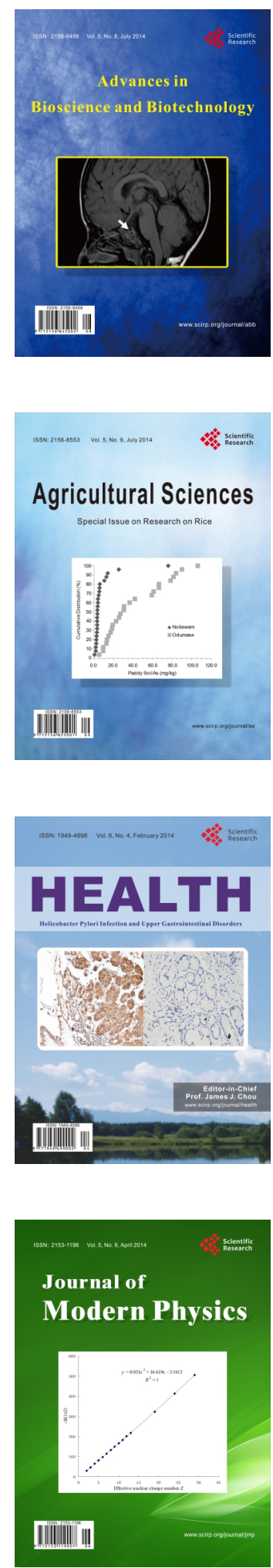
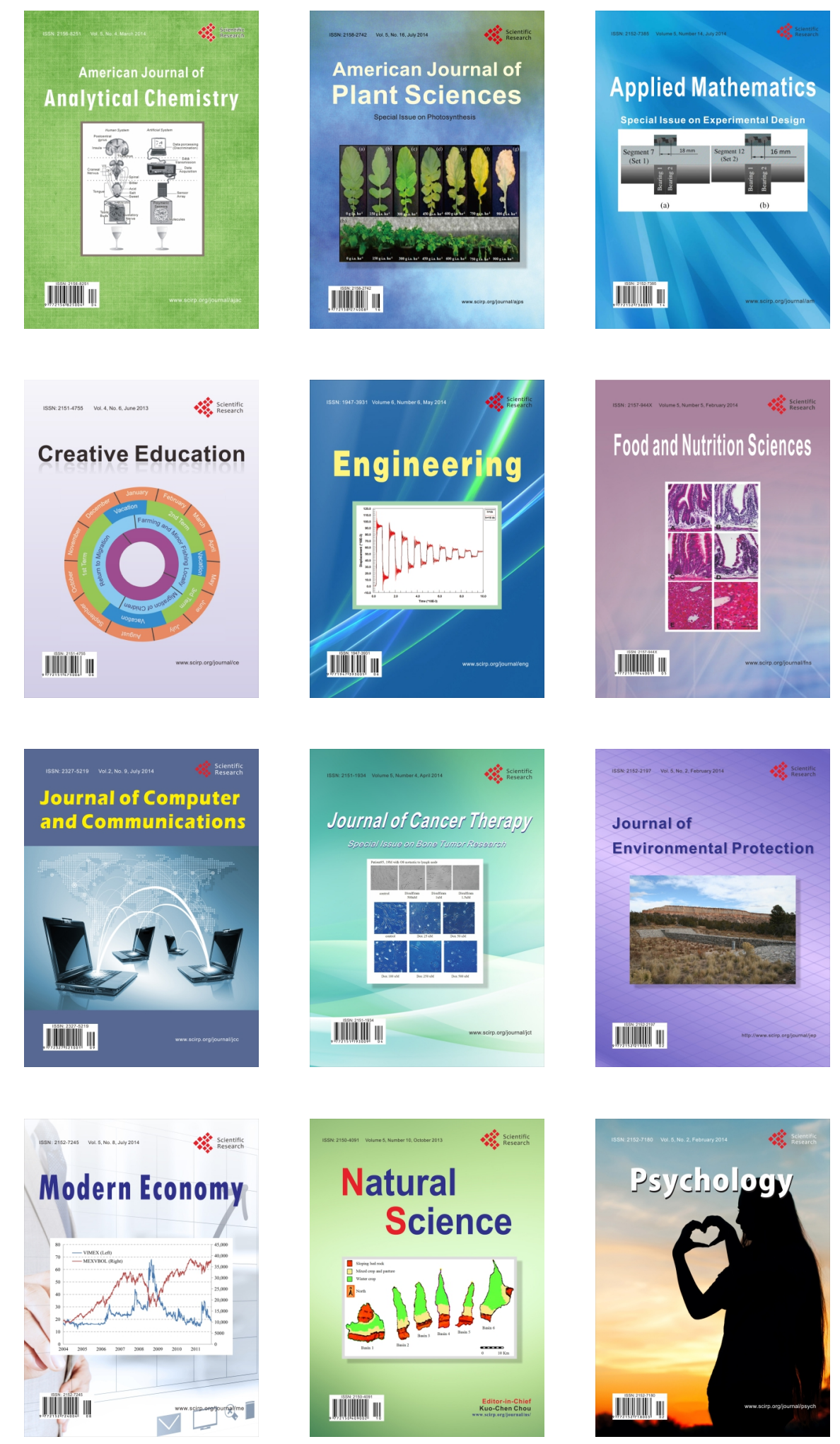